\title{
PERFORMANCE OF A SMALL-SCALE HAND-CRANKED MACHINE FOR MAIZE SHELLING
}

\author{
W. K. El Helew*
}

\section{ABSTRACT}

The aim of this study is to investigate some operational factors relevant to the development of small-sized hand-operated maize shelling machine to be suitable for the Egyptian rural communities. The performance of the developed machine had been done by changing the power source, the rotational speed of shelling disc and cage pressure. However, the following technical indicators had been estimated such as machine productivity, shelling efficiency, visibly damaged kernels percent of maize, shelling energy and operating cost of the maize shelling machine. The results indicated that the most important factors found to affect maize shelling is the rotational speed of shelling disc. Developed machine productivity was found to be $24.8 \mathrm{~kg} / \mathrm{h}$, shelling efficiency was $94.2 \%$., visibly damaged kernels percent of maize was $2 \%$, energy consumed in shelling operation was $0.92 \mathrm{~kJ} / \mathrm{kg}$. It could be concluded that using the developed sheller increased the machine productivity to 1:1.72 and reduced the cost of maize shelling to 1:1.6 as compared with the manual method.

\section{INTRODUCTION}

aize (corn) is one of the most important cereal crops in the
world. Because of its high yield and adaptability to a wide
range of climatic conditions, corn is the preferred feed grain in much of the world. In Egypt, corn is emerging as the third most important crop after rice and wheat, and it has significance as a source of a large number of industrial products besides its use as human food and animal feed. Area and production of maize in Egypt reached 2.168 million feddan, and 7.25 million tons in 2013/2014 (Bul. Ag. Statistics, 2015).

In many rural areas of Egypt, the maize kernels are removed from the cob by hand in a process called shelling. Shelling the annual maize harvest by hand typically takes weeks. In addition, the hardened, dry maize can also

* Assist. Prof., Ag. Eng. Dep., Fac. Ag., Ain Shams U., Cairo, Egypt. 
be painful to shell and lead to hand injuries. As a consequence, farmers may be required to a simple tool robust and portable that makes it possible to shell maize, several times faster than by hand.

Zhang et al. (1991) stated that shear tests, were performed for the frictional response of three types of grain (maize, rice and soybeans) on galvanized steel surfaces for normal pressures between $9.8 \mathrm{kPa}$ and 38.8 $\mathrm{kPa}$ by simulating an empirical model proposed for the pre- and post-peak frictional force as a function of relative displacement. Kumar and Parvathi (1998) observed that for hand-operated corn sheller at a moisture content of $12 \%$ w.b. and at a feed rate of $130 \mathrm{~kg} / \mathrm{h}$, the shelling efficiency, unshelled percentage, and visible damage were found to be $99.56 \%, 0.44 \%$, and $1.07 \%$, respectively.

Abdel Wahab et al. (2011), and El-Fawal (2011) developed and evaluated the performance of a corn shelling machine and found that the optimum drum speed and concave clearance for shelling both yellow and white corn varieties were $7.85-8.77 \mathrm{~m} / \mathrm{s}(500-670 \mathrm{rpm})$, and $40-42$ $\mathrm{mm}$, respectively. Mady (2004) found that the suitable level of kernel moisture content during shelling was $15.5 \%$ with cylinder speed of 450 rpm and concave clearance of $50 \mathrm{~mm}$ which reduced the broken kernels up to $6.5 \%$ and increased the intact kernels up to $93.5 \%$.

Roy et al. (2007) indicated that the power operated maize shellers look like a wise investment ( $5-8$ acres for $25 \%$ internal rate of return or IRR). However, it makes economic sense to operate shellers at higher capacities, and along with the high capital cost (257 - 314 US\$) to save large numbers of laborers and maize traders. Milufarzana, et al. (2015) stated that the operating cost of maize sheller was US\$ 3.4 per hour or US\$ 1.41 per ton. Based on the operating cost, annual savings for replacement and a profit margin for the entrepreneur, the rent-out charge of the maize sheller is estimated as US\$ 8.15 per hour or US\$ 3.21 per ton. The benefit-cost ratio of maize sheller is found 2.34, which is a highly profitable venture for an entrepreneur. The break-even use for maize sheller is estimated as $670 \mathrm{~h}$ of operation or $1705 \mathrm{t}$ of maize shelling. Singh (2013) found that to reduce the physiological cost by $38.95 \%$ and $21.62 \%$ in dehusking and shelling, with the hand, and 
dehusking by hand \& shelling by octagonal maize sheller respectively. Adewole et al. (2008) showed that petrol engines are using to power the shelling maize machine and the average throughput capacity of the machine is $360.8 \mathrm{~kg} / \mathrm{h}$ and fuel consumption rate $0.0154 \mathrm{lit} / \mathrm{min}(0.924$ lit/h).

Nkakini et al. (2007) evaluated sheller using abrasion between a rotating disc and stationary concave to achieve stripping. A manually - operated handle is used to rotate two shafts, one of which translates rotational motion to become linear with a slider crank. The slider pushes the maize cobs into the sheller continually one after another. Though manually operated, the sheller can provide a continuous flow; the kernels being collected via a chute. At a speed of $60 \mathrm{rpm}$, a shelling effectiveness of $67 \%$ was achieved, with a low kernel-breakage factor of 0.090 and a throughput of $6.82 \mathrm{~kg} / \mathrm{h}$. Karikatti et al. (2015) developed a crank operated maize sheller using ergonomic and mechanical considerations for dehusking and shelling. It consists of a feeder from where the maize is inserted. The crank is connected to the blade. When the crank is turned, the blade rotates and shells the maize. One person is required to operate the machine and the feeding of cobs one by one.

As a result of a shortage in agricultural laborers, higher wages, and hand injuries, this research contributes to the development of small-sized maize shelling machine to be suitable for the Egyptian rural communities.

The aim of this study is to develop a small-scale hand-cranked maize sheller for use in rural homes (rural women) or small quantities.

The specific objectives of the research are to 1) Develop and test a small sheller, 2) Investigate the factors affecting the shelling process, 3) Estimate the shelling rates and efficiencies, 4) Estimate the power requirements for shelling process, and 5) Determine the cost of the motorized sheller by using maize shelling.

\section{MATERIALS AND METHODS}

\section{Description of maize sheller}

A small-scale hand-cranked machine locally made was modified for maize shelling in the Fac. of Agric., Ain Shams Univ. The construction 
and dimensions of developed maize sheller are shown in figure (1). The main parts of the sheller consist of:

a) Feeding tube: A cast iron tube of two halves (7.5- $\mathrm{cm}$ diameter and 8-cm length), one half of the tube is fixed in the sheller frame and the other half moves with the sheller frame to insert the maize cobs into the shelling unit.

b) Shelling unit: A toothed disc of cast iron $18-\mathrm{cm}$ diameter and mounted on the shaft (11-cm long and 18-mm diameter) rotating through two ball bearings fixed in the frame as a shelling disc. The shelling disc surface includes 92-conical teeth distributed in 5rings $(6.2,8.6,11.6,15.6$, and 16.8-cm diameters) having a base of $10-\mathrm{mm}$ diameter and $10-\mathrm{mm}$ long. The half of the feeding tube is extended and enclosed a part of the shelling disc over a certain area (4-cm diameter and 11-cm length), forming the shelling cage having 6-rectangular openings $29 \times 5-\mathrm{mm}$ to prevent the shelled kernels jam and 6-helical threads with a $20^{\circ}$ helix angle to hold and forward spirally the corn cob during the shelling process. A screw bolt and spring-loaded (compressing spring) are used to self-adjust the size of the cage clearance according to the size of the corn cobs and hold the ear against to the shelling disc while shelling takes place.

c) Shelling power unit: A wood handle $8.5-\mathrm{cm}$ length mounted on steel pin fixed in the pulley of aluminum alloy $20-\mathrm{cm}$ diameter (flywheel) is used as a crank to rotate the shelling disc manually. With one hand, a person operates crank of the sheller, whereas cobs are fed by the other hand, one by one. An electric motor $1 / 4$ $\mathrm{kW}, 1500 \mathrm{rpm}, 220 / 240 \mathrm{~V}, 3 \mathrm{Amp}$, and 50Hz" (1B) replaced the handle to convert human power into mechanical rotation to minimize the work for the operator and increase rotational speed of the shelling disc. A V-belt and two pulleys are used to transmit the motion from the motor to the shelling disc to give a reduction ratio of 1.8:1. 

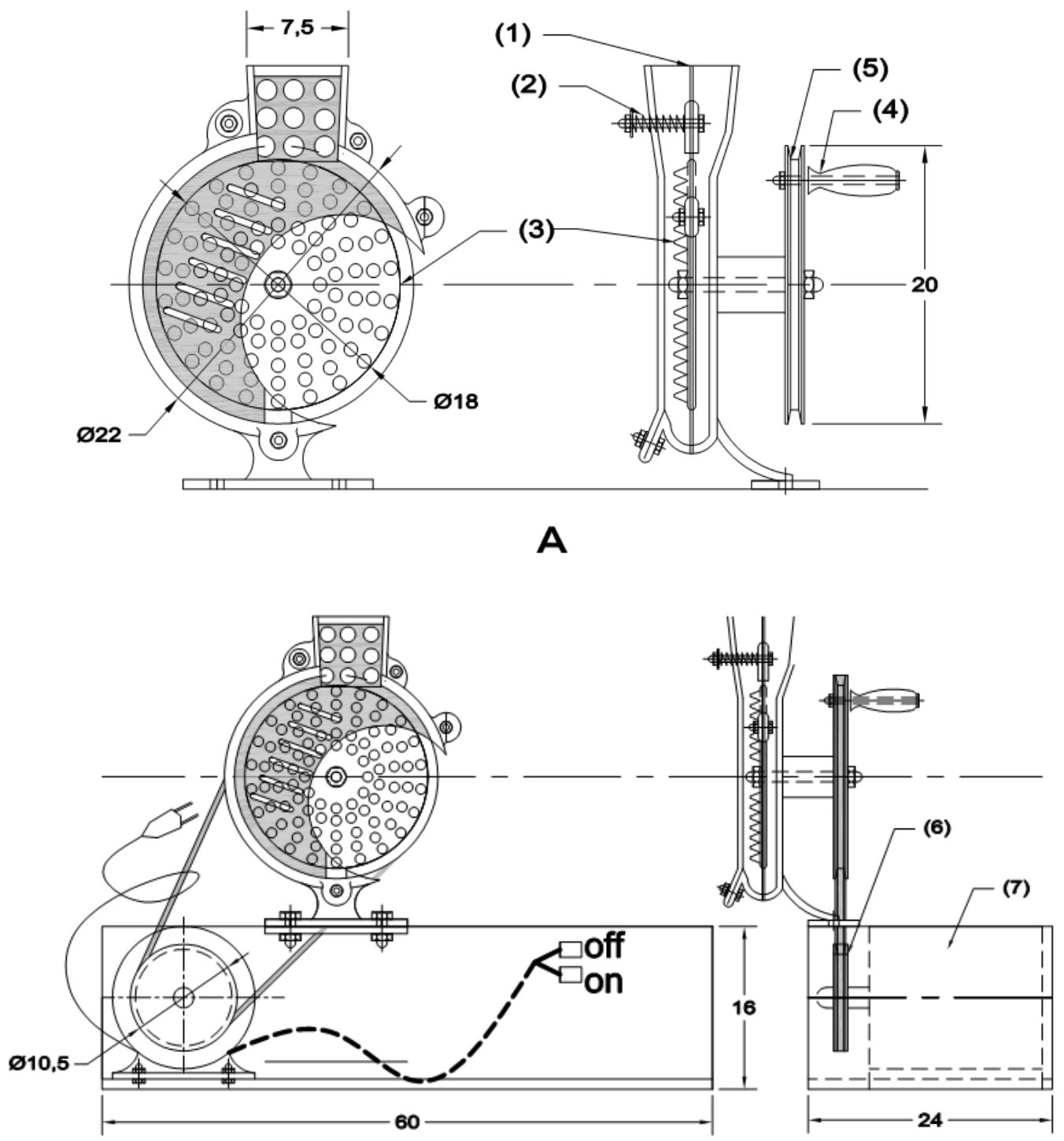

B

Dims. in cms

(1) Maize feeding tube

(2) Spring-loaded cage

(3) Shelling disc

(4) Crank handle

(5) Shelling-disc pulley

(6) Motor pulley

(7) Electric motor.

Figure 1: Maize shelling machine, (A) without a motor, (B) with an electric motor. 


\section{Maize cobs}

The variety of the maize (single cross 10) was used in this investigation. A representative sample of maize cobs, air dried and dehusked, was taken randomly, to measure the dimensions, mass and moisture content. The mean length of cobs was 18-cm (figure (2-a), the mean diameter of cobs was $4.3-\mathrm{cm}$ (figure (2-b), the mean mass of cobs was 213.5-g and the mean moisture content of cobs was $7.62 \%$ w.b.

A vernier caliper was used to measure the dimensions of the cobs with an accuracy of $0.05-\mathrm{mm}$.

The maize was weighed using a sensitive digital electronic balance with an accuracy of $0.1-\mathrm{g}$.

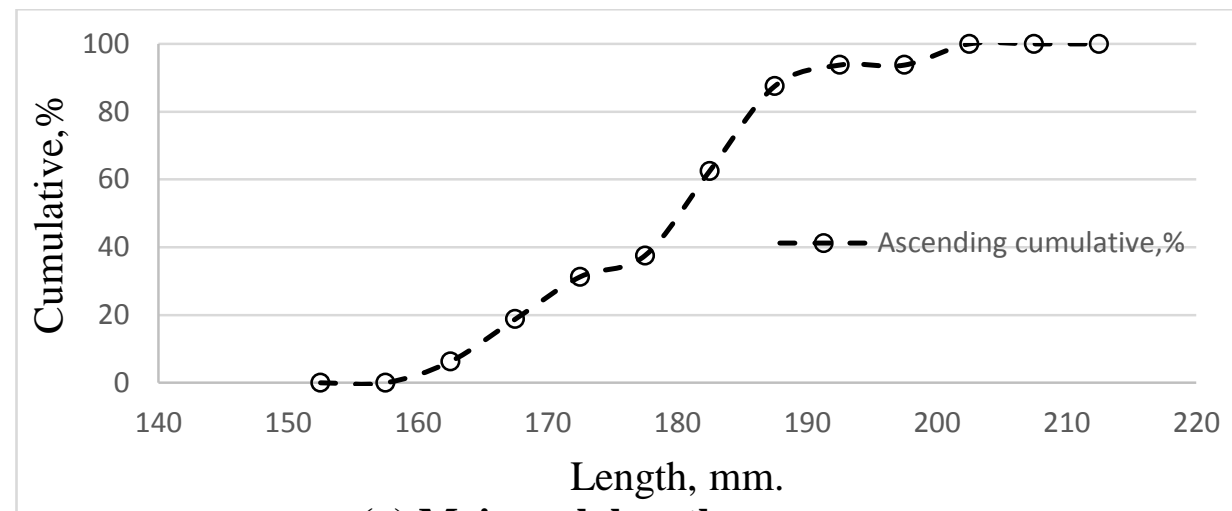

(a) Maize cob length.

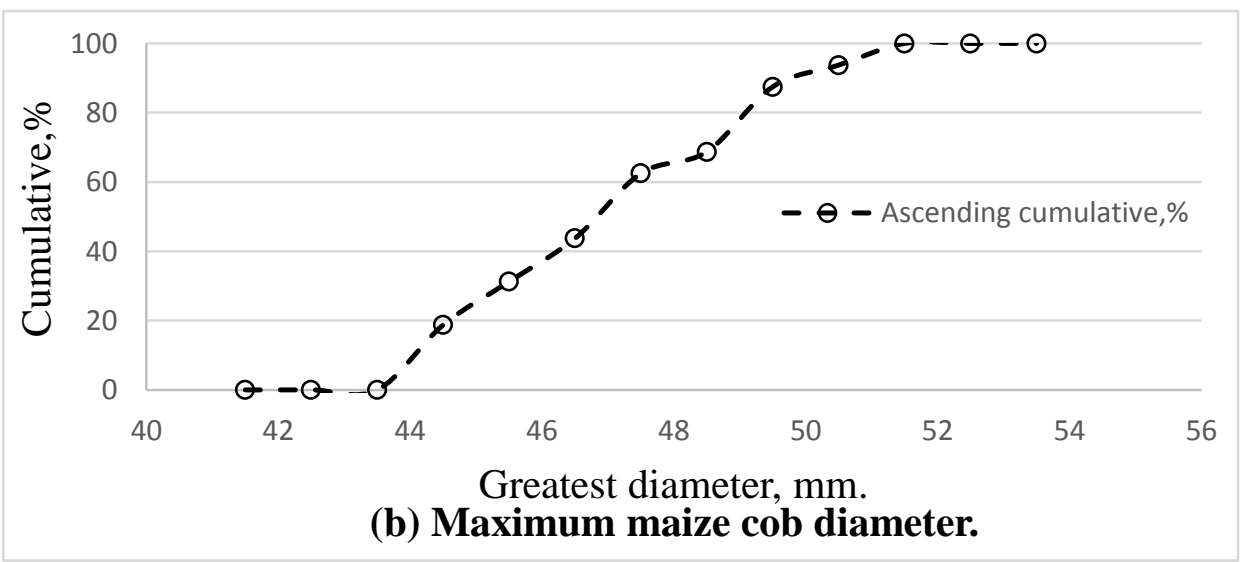

Figure 2: The maize cob length and greatest diameter distributions. 
A stopwatch was used to estimate the shelling process time with an accuracy of 0.01-s.

\section{Compact inverter}

Compact inverter "Frenic-Mini, Fuji Electric (FA) components and systems Co., Ltd, SN. INR-S147-0791C-E" device was used to change the rotational speed of the electric motor and measure the voltage, current, and input power.

\section{Calibration of spring cage pressure}

The calibration of pressure gate spring was determined using benchtop materials testing machine (Tinius Olsen-model H5ks - UK) according the procedure described by Ozcan and Haciseferogullari (2007). Calibration force was measured by the data acquisition system and using Qmat software (developed by Tinius Olsen Co.) based on relation between deformation distance and spring force. Experiment was conducted at a loading velocity of $50 \mathrm{~mm} / \mathrm{min}$.

From calibration of pressure gate spring, the relationship between the spring length change " $\Delta \mathrm{L}$ " and the pressure force " $F$ " is as follows:

$$
\mathrm{F}=9.94 \Delta \mathrm{L}
$$

According to Eq (1), $1 \mathrm{~mm}$ length needs about $9.94 \mathrm{~N}$.

\section{Test procedures:}

Factors which affect the shelling process were investigated by conducting numerous small experiments. Three rotational speeds of the shelling disc of 7.5, 10, 12.5 and 15-rps and three cage pressures of 0,50 and 100-N were used to evaluate the motorized sheller performance. At all levels of these factors, the shelling machine productivity, field efficiency, shelling efficiency and visibly damaged kernels percent of maize were estimated. The shelling energy consumed was also studied, in addition to the operating cost of the shelling process using motorized sheller was compared with both hand-cranked machine and manual shelling.

The main calculations can summarized as follows:

\section{1- Feeding rate}

The feeding rate has been calculated according to the formula:

$$
\text { Feeding rate }(\mathrm{mm} / \mathrm{s})=\frac{\text { Maize length } " \mathrm{~L} ", \mathrm{~mm}}{\text { Net shelling time } \mathrm{tn}, \mathrm{s}}
$$




\section{2- Sheller productivity}

Sheller productivities had been calculated according to the formula:

$$
\begin{gathered}
\text { Theoretical productivity }\left(\frac{\mathrm{kg}}{\mathrm{h}}\right)=\frac{\text { Mass of shelled maize " } M \text { ".kg }}{\text { Net shelling time " } \mathrm{t}_{n} \text { ".h }} \ldots \text { (3) } \\
\text { Actual productivity }(\mathrm{kg} / \mathrm{h})=\frac{\text { Mass of shelled maize " } M \text { ".kg }}{\text { Total shelling time " } t_{t} \text { ".h }}
\end{gathered}
$$

\section{3- Working efficiency}

The working efficiency $\left(\boldsymbol{\eta}_{w}\right)$ for each treatment was determined using the formula:

$$
\eta_{w}(\%)=\frac{\text { Actual shelling productivity }(\mathrm{kg} / \mathrm{h})}{\text { Theoretical shelling productivity }(\mathrm{kg} / \mathrm{h})} \times 100 \ldots(5)
$$

\section{4- Visible damage}

Visible damage kernels from the specified kernel outlet with respect to total kernel received at outlet is expressed as a percentage by weight.

Visible damage $(\%)=\frac{\text { Broken kernels from specified outlets in } \mathrm{kg}}{\text { Total kernels input in } \mathrm{kg}} \times 100$...(6)

\section{5- Shelling energy requirements}

To determine energy consumption, it was required to measure the energy consumed by the load, disregarding the amount of energy stored and returned to the source. The ratio of the "True Power" consumed, to "Apparent Power" is the "Power Factor": $\cos (\phi)$.

$$
\text { Power }(\text { Watt })=\text { Apparent Power }(\text { VA) } x \text { PF ... (7) }
$$

Energy consumed "kJ/kg" $=\frac{\text { Watt Power } \times \text { Net shelling time " } t_{n} " . h}{\text { wieght of shelled maize " } M " . k g} \times 3.6 \ldots(8)$

Energy consumed for shelling " $\mathrm{kJ} / \mathrm{kg}$ " = Energy consumed with

$$
\text { shelling - Energy consumed without shelling ...(9) }
$$

$$
\text { Torque "T", in N.m }=\frac{\text { Power }}{2 \pi N}
$$

Where, N: speed, r/s.

\section{6- Operating costs}

The cost per unit of shelled maize was determined using the following equation according to Awady (1978): 


$$
C=P / h(1 / e+i / 2+t+r)+(W * f)+S / 144 \ldots(11)
$$

Where: $\boldsymbol{C}$ : Hourly cost in L.E., $\boldsymbol{P}$ : Capital investment in L.E., $\boldsymbol{h}$ : Yearly operating hours, $\boldsymbol{e}$ : Life expectancy in years, $\boldsymbol{i}$ : Interest rate, $\boldsymbol{t}:$ Taxes and overhead ratio, $r$ : Repairs ratio to the total investment, $\boldsymbol{W}$ : Power of motor in $\mathrm{kW}, f$ : Power unit price in L.E., $S$ : Labor salary rate per month in L.E.and 144: Reasonable estimation of monthly working hours.

\section{Operating cost "L.E./kg" = C / Actual productivity "kg/h" ...(12) \\ RESULTS AND DISCUSSION}

Testing of the product is carried out to find the advantage over the maize shelling by 3 systems: (1) for a maize shelling machine to be operated by a 1/3-hp (1/4-kW) electric motor, (2) for crank handle operated sheller, and (3) for manual maize shelling for comparison.

\section{Effect of shelling disc speed and cage pressure on cob feeding speed}

Figure (3) shows comparing the cob feeding speed of the shelling maize machine at different rotational speeds and spring cage pressures. The curves indicate that:

- When the rotational speeds of the machine and spring cage pressures increased, the cob feeding speed increased, due to increased shelling disc movement energy, and friction between the cob and sheller cage.

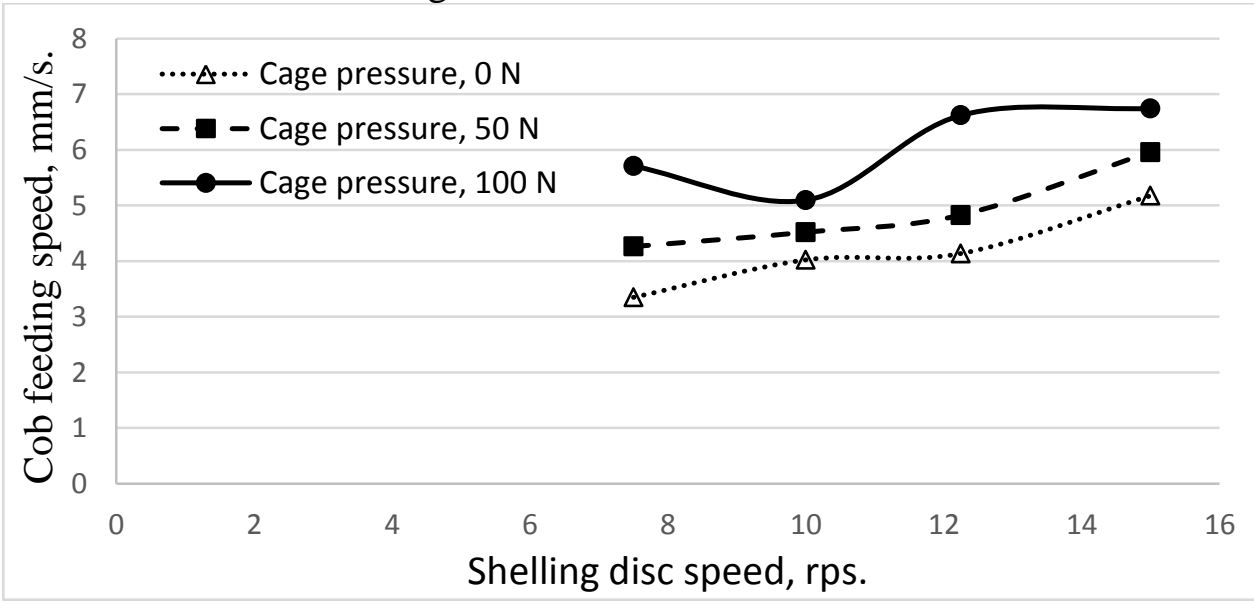

Figure 3: Effect of shelling disc speed and cage pressure on feeding speed. 
- Cob feeding speed ranged from 3.35 to $6.75 \mathrm{~mm} / \mathrm{s}$.

- Greatest cob feeding speed of the machine was $6.75 \mathrm{~mm} / \mathrm{s}$ when the rotational speed is $15 \mathrm{rps}(900 \mathrm{rpm})$, and $100 \mathrm{~N}$ spring pressure cage.

\section{Shelling machine productivity and working efficiency}

Figure (4) shows comparing the productivity of the shelling maize machine at different rotation speeds and spring cage pressures. The curves indicate that:

- When the rotational speeds, of the machine increased, the productivity increased at the same spring cage pressures, due to increased cob feeding speed.

- Machine actual productivity ranged from 5.5 to $24.8 \mathrm{~kg} / \mathrm{h}$.

- Greatest productivity of the machine was $24.8 \mathrm{~kg} / \mathrm{h}$ when the rotational speed is $15 \mathrm{rps}(900 \mathrm{rpm})$, and $100 \mathrm{~N}$ spring pressure of cage.

- When the rotational speeds of the machine increased, the working efficiency increased compromising rotation speed of $10 \mathrm{rps}$, then the working efficiency either stayed or slightly increased at the same spring cage pressures.

- Working efficiency ranged from 43.6 to $94.2 \%$.

Figure (5) shows comparing the maximum actual productivity of the motorized sheller and crank handle operated sheller at different spring cage pressures. The curves indicate that:

- When the spring pressure cage increased, the productivity increased, due to increased maize cob friction with the sheller disc and cage.

- Crank handle operated shelling machine actual productivity ranged from 5.9 to $17 \mathrm{~kg} / \mathrm{h}$.

- Greastest actual productivity of the crank handle operated sheller was $17 \mathrm{~kg} / \mathrm{h}$ at $100 \mathrm{~N}$ spring pressure cage.

The average manual maize shelling was about $14.4 \mathrm{~kg} / \mathrm{h}$ per worker. 
Cage pressure, $0 \mathrm{~N}$

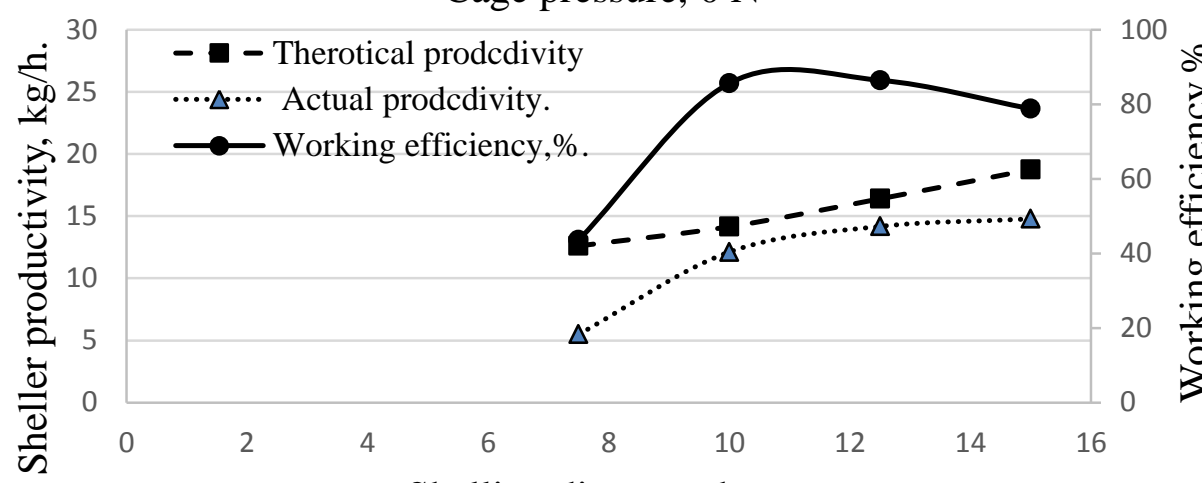

Shelling disc speed, rps.

Cage pressure, $50 \mathrm{~N}$
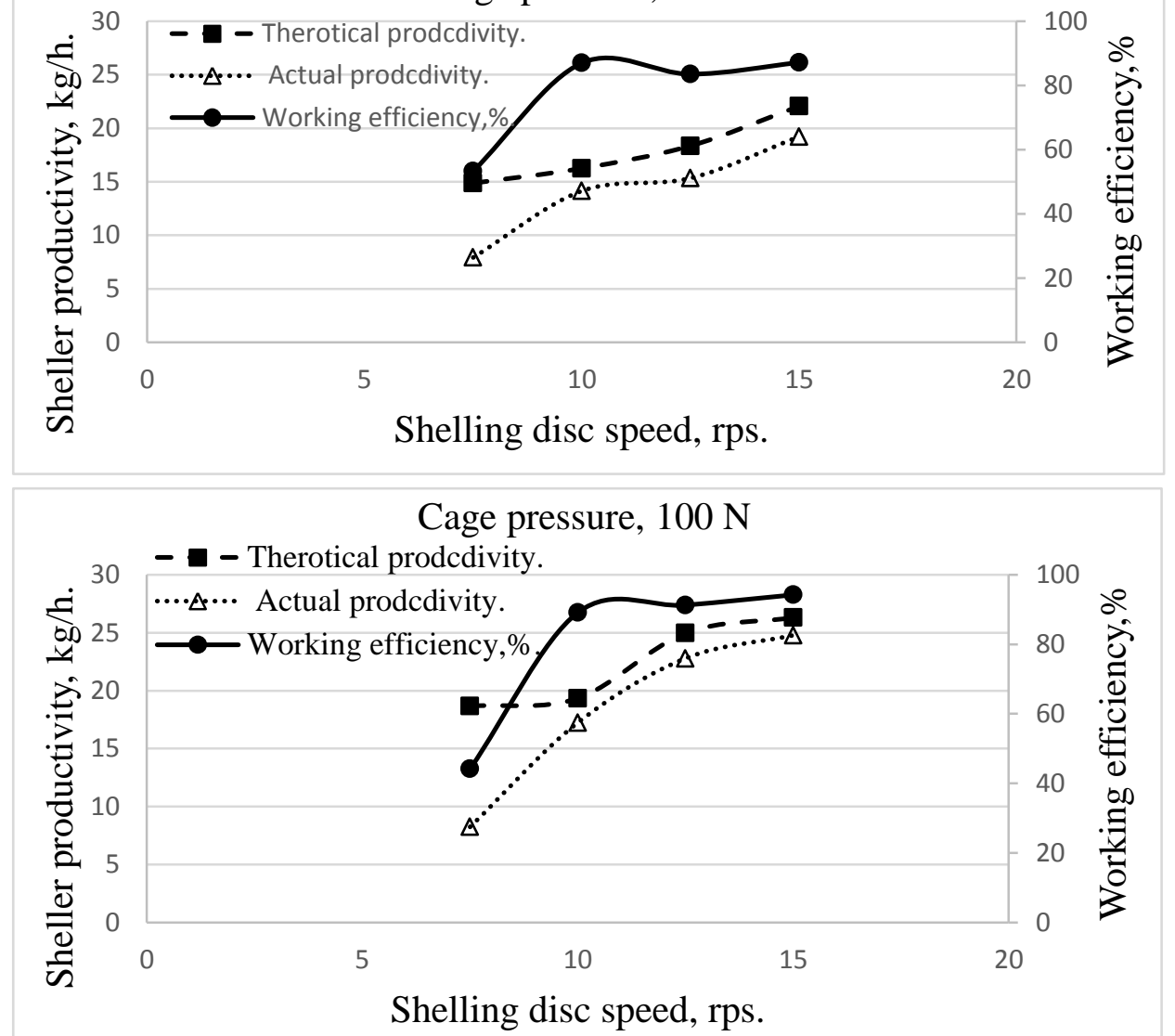

Figure 4: Productivity and working efficiency of the machine at different rotational speeds and spring cage pressures. 


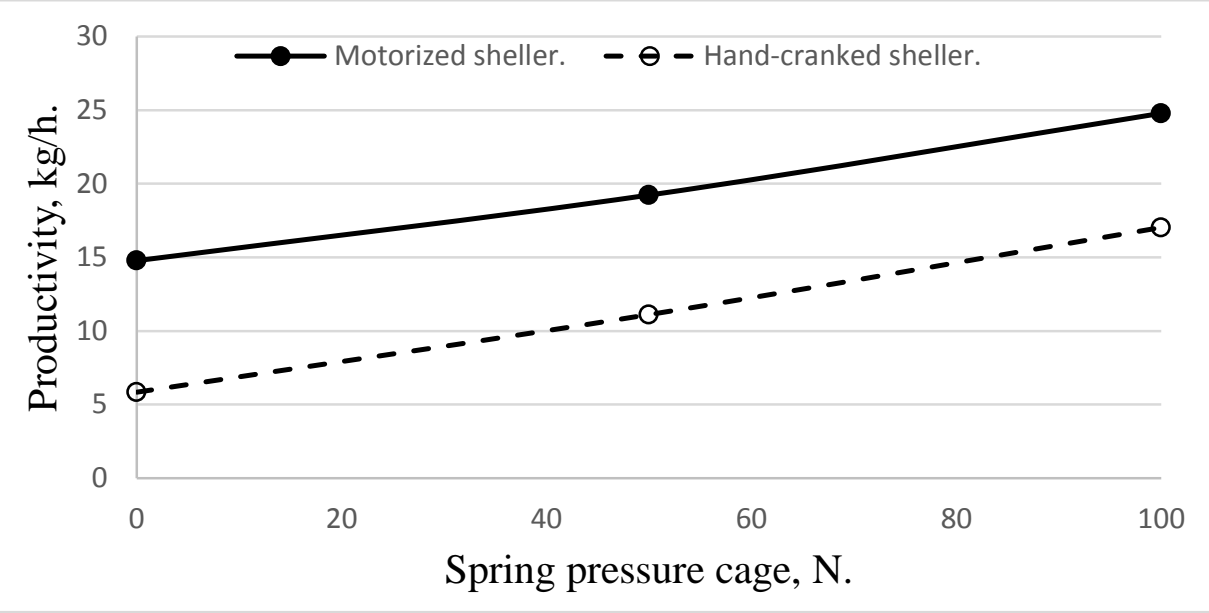

Figure 5: Comparison between the maximum actual productivity for motorized sheller, and hand crank operated sheller at different spring pressures.

\section{Maize kernels shelled quality (vs. broken kernel\%)}

Figure (6) shows the effect of motorized maize shelling machine speed on the mass of visible damage of maize. The curves indicate that:

- When increasing rotational speed of shelling disc, the mass of broken grains increased with different spring pressures, due to increased shelling disc movement energy, and friction with the cob with sheller disc and cage.

- Visible damage of maize percentage ranged from 5.8 - 39.6\%.

- Greatest visible damage of maize percentage of the machine was $39.6 \%$ when the rotational speed was $15 \mathrm{rps}$ (900 rpm), and $100 \mathrm{~N}$ spring pressure cage.

Figure (7) shows the effect of maize shelling machine spring pressure cage on the mass of visible damage of maize. The curves indicate that:

- When increasing spring pressure cage, the mass of broken grains increased, due to increased maize cob friction with the sheller disc and cage.

- Visible damage of maize percentage decreases when shelling machine is cranked.

- Greatest visible damage of a maize percentage of the crank handle operated sheller was $2.1 \%$ at $100 \mathrm{~N}$ spring pressure cage.

The visible damage of maize percentage was nil when shelling by hand. 


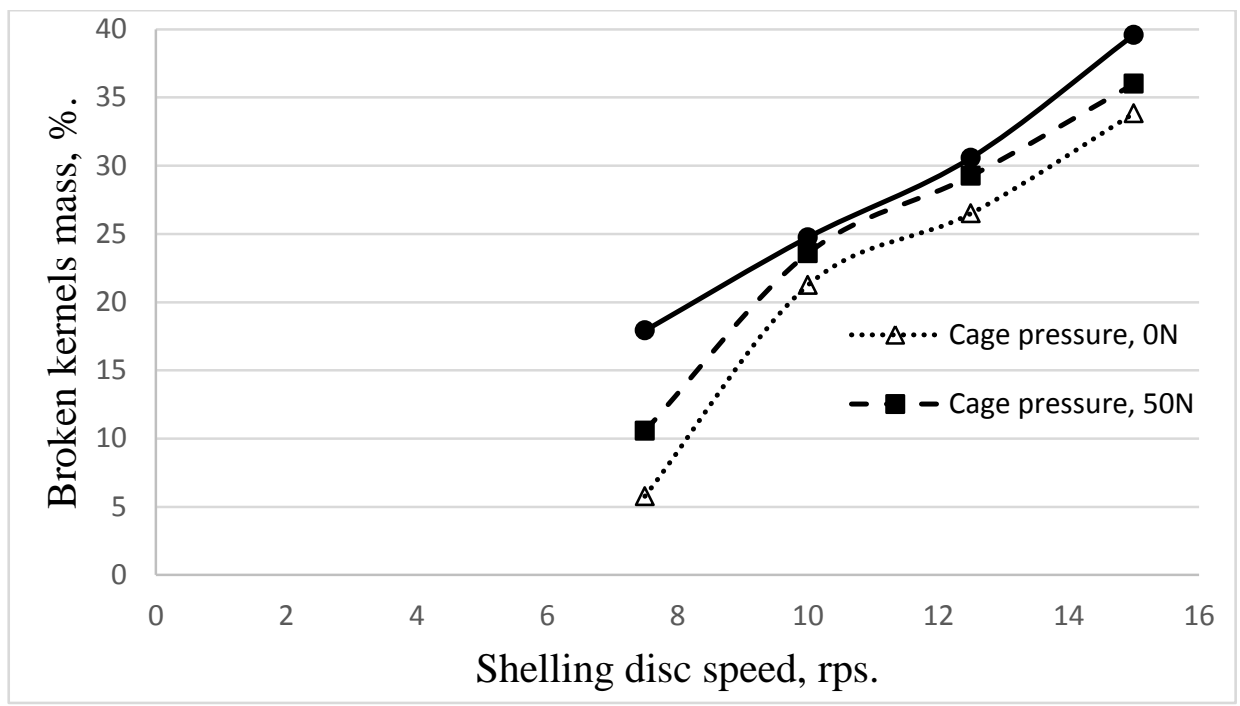

Figure 6: Broken kernels percentage at different shelling disc speeds and spring pressures.

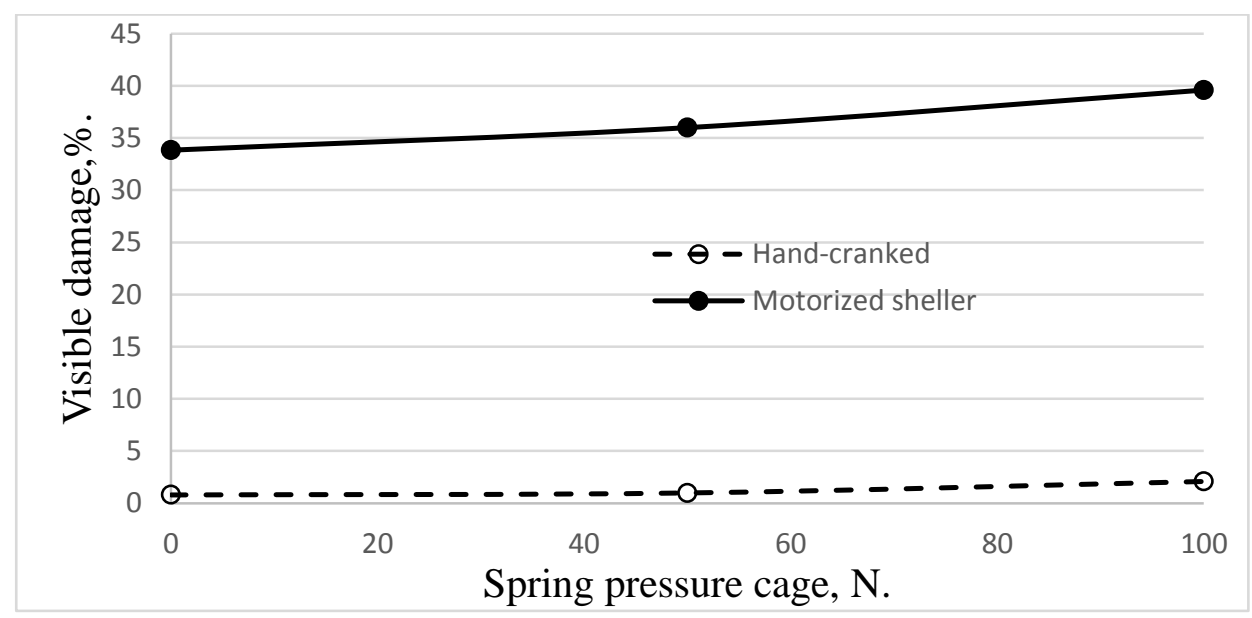

Figure 7: Comparison between broken kernels percentage for motorized sheller, and hand-cranked sheller at different spring pressures.

Energy consumed for maize shelling

Figure (8) shows the mean machine energy consumed per kilogram of maize kernels at the different rotational speeds of shelling disc. The curves indicate that: 
- When increasing rotational speed of shelling disc, the maize sheller energy increased, because the machine power increased with the speed of shelling disc.

- The energy ranged from 18.7 to $32 \mathrm{~kJ} / \mathrm{kg}$ kernels with speeds of 7.5 to $15 \mathrm{rps}(450-900 \mathrm{rpm})$ to operate the machine with maize shelling.

- The energy ranged from 17.8 to $31.2 \mathrm{~kJ} / \mathrm{kg}$ kernels with speeds of $7.5-15 \mathrm{rps}(450-900 \mathrm{rpm})$ to operate the machine without maize shelling.

- The average energy consumed in shelling only (the difference between load and without load) amounted to $0.92 \mathrm{~kJ} / \mathrm{kg}(0.51$ to $1.47 \mathrm{~kJ} / \mathrm{kg}$ ).

- The average torque required to rotate the machine was about 1.9 N.m. (19 N to rotate the machine arm length of $10 \mathrm{~cm})$.

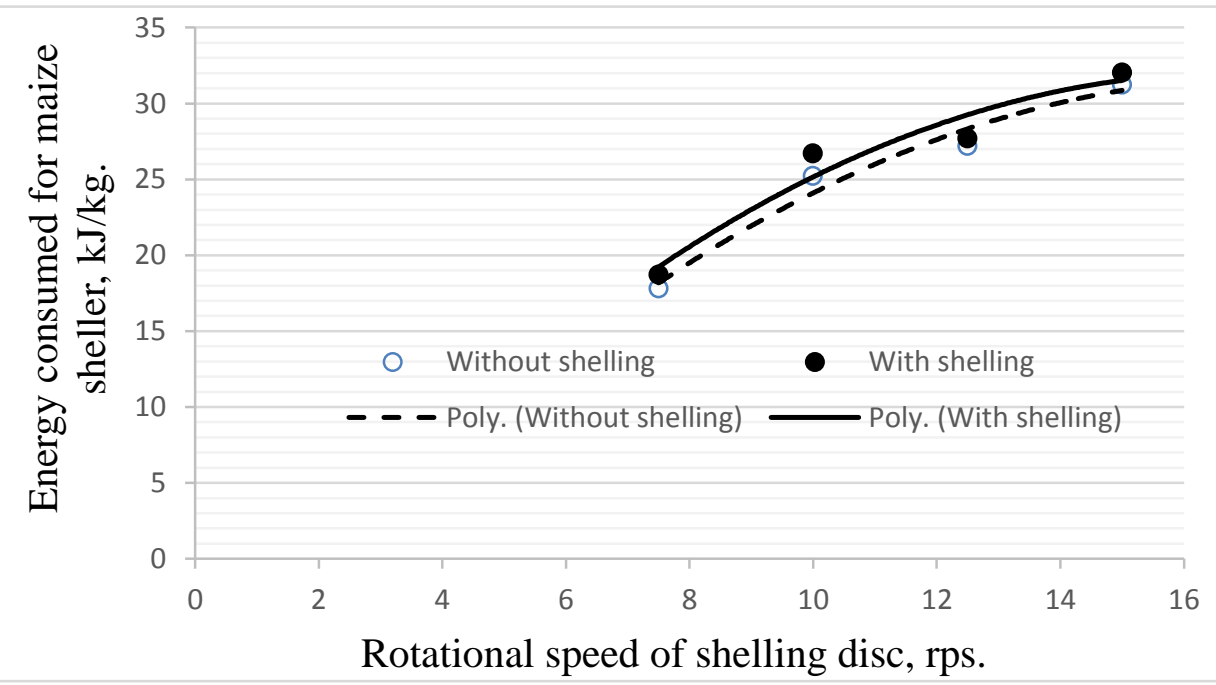

Figure 8: Mean machine energy consumed per kilogram of maize kernels.

Costs of motorized sheller, hand-cranked sheller, and manual shelling:

The cost of maize shelling per kg is estimated for 3 systems: (1) for the motorized maize sheller operated by a $1 / 4 \mathrm{~kW}$ electric motor, (2) for the 
crank handle operated sheller, and (3) for manual maize shelling for comparison, by using the expression that mentioned earlier in material and methods section, figure (9). The following assumptions were used (according to the current Egyptian conditions): initial price of motorized sheller " $\mathrm{P}_{1}$ " $=750$ L.E., crank handle operated sheller " $\mathrm{P}_{2}$ " $=250$ L.E., working hours per year " $h "=320 \mathrm{~h}$, life expectancy "e" $=10$ years, annual interest " $\mathrm{i}$ " $=0.12$, annual taxes " $\mathrm{t}$ " $=0.05$, annual repairs and maintenance " $r "=0.1$, the total power "W" $=1 / 4 \mathrm{~kW}$, power unit price “f” $=0.25$ L.E. $/ \mathrm{kW} . \mathrm{h}$, and operator monthly salary "S" = 1500 L.E.

Comparison of costs for the 3 studied systems: Figure (9), shows the three cases as follows:

Case (1): for the motorized maize sheller operated by a $1 / 4 \mathrm{~kW}$ electric motor $=0.45$ L.E. $/ \mathrm{kg}$ "450 L.E/ton". Case (2): for the crank handle operated sheller $=0.63$ L.E. $/ \mathrm{kg}$ "630 L.E/ton". Case (3): manual maize shelling (for comparison) $=0.72$ L.E. $/ \mathrm{kg}$ "720 L.E/ton".

From the above, it is seen that the utilization of the maize shelling machine is most feasible for yearly operation, compared with the manual maize shelling methods.

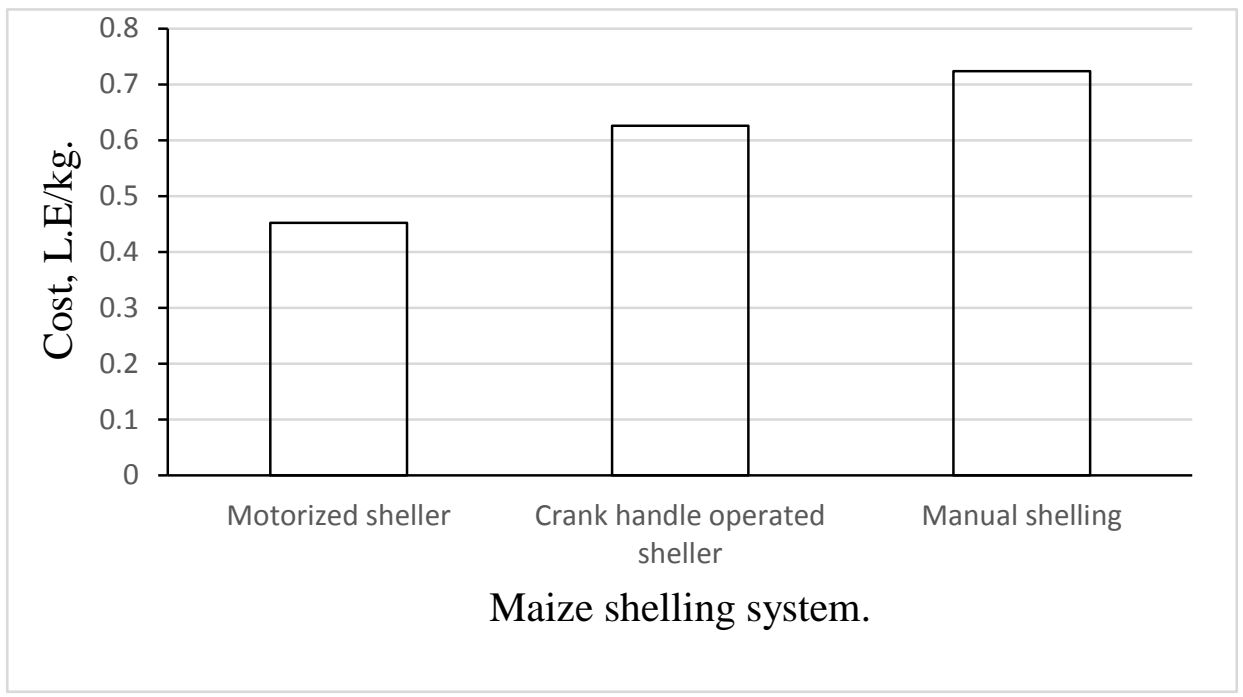

Figure 9: Costs of motorized, hand-cranked, and manual shelling. 


\section{Recommendations:}

- The motorized maize sheller, and crank handle operated maize sheller can be used for the Egyptian rural communities (small quantities or home use).

- It is preferable to use the motorized maize sheller when you need to use for direct feeding.

- It is preferable to use the hand-cranked maize sheller or the manual operated maize shelling machine for planting or for use as intact grains.

\section{REFERENCES}

Abdel Wahab, M. K., S. E. Bader, Hanan M. El-Shal, and Amany M. ElSafy (2011). "Engineering studies on the factor affecting the performance of shelling and grading corn machine"., Misr J. Ag. Eng., 28(1): $32-47$.

Adewole, C. A., T. M. Babajide, A. M. Oke, N. A. Babajide, D. O. Aremu, and Ogunlade, C. A., (2015). "Critical Evaluation of Locally Fabricated Maize Shelling Machine” I. J. of Eng. Sc. and Innovative Tec. (IJESIT). 4 (2): 67 - 73.

Awady, M. N. (1978). "Tractors and farm machinery". Txt. Bk. Col. Ain Shams U., P: 164-164.

Bul. Ag. Statistics, (2015). part (2), Summer and Nili crops, 2013/2013, P: 9,14.

El-Fawal, Y. A. (2011). "Study of some effective parameters on mechanical shelling and grading corn crop". Misr J. Ag. Eng., 28(4): $837-853$.

Karikatti, G. J., J. Satish, A. Kathani, R. Lokeshwar, and S. Sattur (2015). "Crank operated maize sheller", IJSRD - "I. J. for Sc. Res. and Dev.", 3 (4): 560-564.

Kumar, V. J. F. and Parvathi, S. (1998). "Ergonomic studies on manually operate maize Sheller", Ag. Eng. J., 7(1): 37-45. 
Mady, M. A. (2004). "Development and evaluation of power operated corn sheller”, J. Ag. Sc. Mansoura U. 29(8): 4613 - 4628.

Milufarzana, A. R., M. M. Alam, and M. R. Ahmed (2015). "Economic parameter of maize sheller for custom hire service in Bangladesh". Ag. Eng. Int: CIGR Journal, 17(2):146-150.

Nkakini, S. O., M. J. Ayotamuno, G. P. D. Maeba, S. O. T. Ogaji, and S. D. Probert (2007). "Manually-powered continuous-flow maizesheller", App En., 84(12): 1175-1186.

Ozcan, M. M., and H. Haciseferogullari (2007). "The strawberry fruits; Chemical composition", phys. properties and mineral contents. J. Food Eng. 78: 1022-1028.

Roy, S., M. Albu and A. Rob (2007). "Business rationale for investment on power operated maize sheller in Bangladesh". Ag. Eng. Int: the CIGR J., 9(3): 1-13.

Singh, S. P. (2013). "Ergonomical evaluation of hand operated maize dehusker-sheller with farm women". Ag. Eng. Int: CIGR J., 15(2): $194-202$.

Zhang, Q., V. M. Puri, and H. B. Manbeck, (1991). "An empirical model for friction force versus relative displacement between maize, rice and soybeans on galvanized steel” J. of Ag. Eng. Res., 49: 59-71.

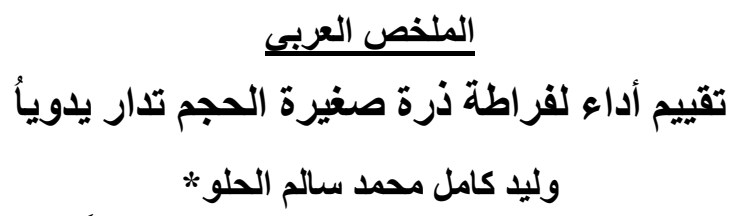

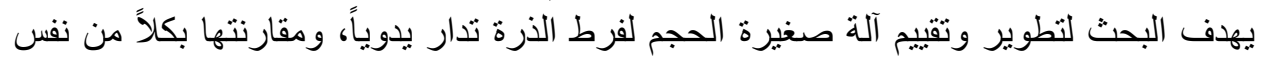

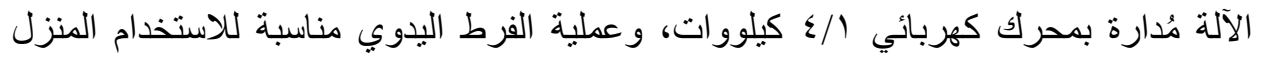

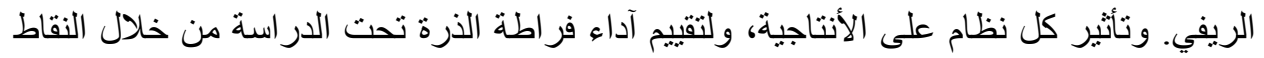

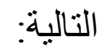

در اسة التلف الظاهري لحبوب الذرة لكل نظام.

الطاقة المستخدمة لكل نظام، وعزم الدور النان اللازم لإدارة الفراطة.

* مدرس الهندسة الزراعية، زراعة عين شمس، القاهرة - مصر. 
حساب التكلفة للأنظمة الثناث.

و التوصية بأفضل نظام مناسب لظروف المساحات الصغيرة و الأستخدام المنزلي.

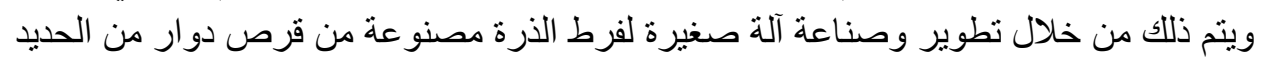

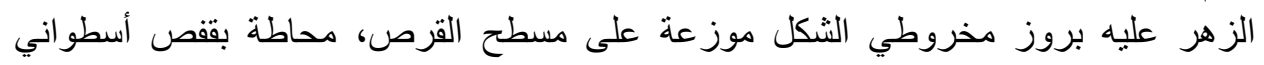
مفصلي يساعد على فرط وخروج الذرة من الجوانب. يُدار القرص من خليط خلاج يد على على محيط

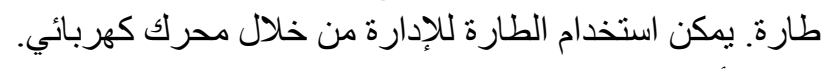
وكاتت أهم النتائج كالتالّي:

أقصى انتاجية لفر اطة الذرة المدارة بالمحرك كهربائي ^, ؟ ك كج/ساعة أي ما يعادل حو V,9

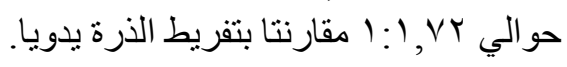

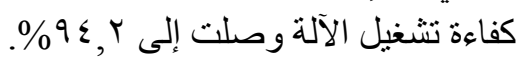

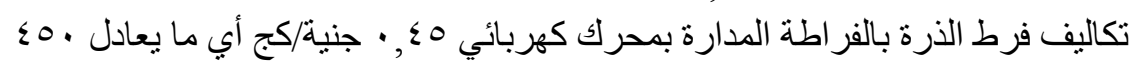

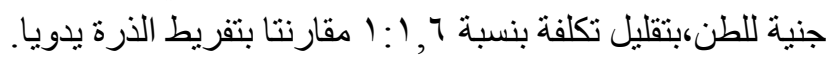

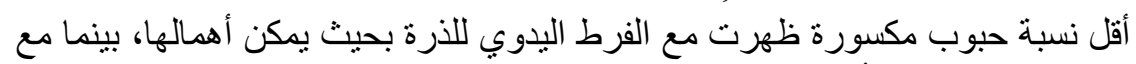

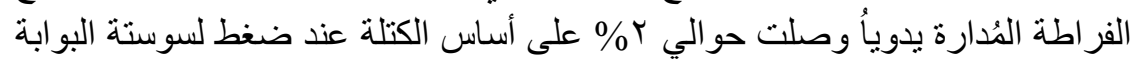

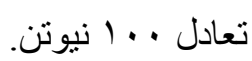

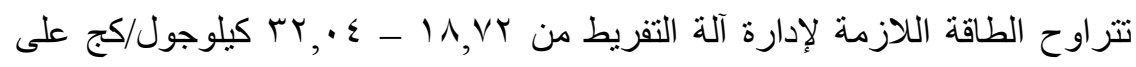

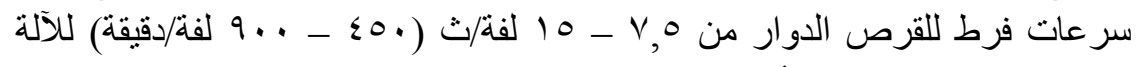

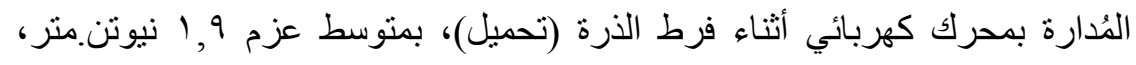

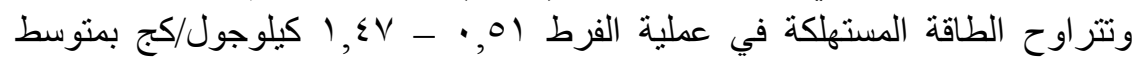

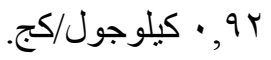

